УДК 343.341

DOI https://doi.org/10.32849/2663-5313/2020.6.44

Костянтин Гаврилюк,

аспірант відділу аспірантури і докторантури

Національної академії Служби безпеки України

\title{
ПОРІВНЯЛЬНИЙ АНАЛІЗ ЗАБЕЗПЕЧЕННЯ АНТИТЕРОРИСТИЧНОЇ БЕЗПЕКИ В УКРАЇНІ ТА РОСІЙСЬКІЙ ФЕДЕРАЦІЇ
}

У статті розглянуто нормативно-правове забезпечення антитерористичної безпеки в Україні та Російській Федерачії. Встановлені відмінності, що грунтовно відрізняють погляди на антитерористичну безпеку.

Свогодні загроза тероризму має міжнародний характер. Терористичні організаиій в переважній більшості мають транснаціональний характер, а тому підготовка до теракту, місце його здійснення інаслідки поширюються на кілька ( $і$ більше) країн. Крім того, змінюються та еволюиіонують способи скоєння терактів: використовуються новітні види озброєння, здійснюється вплив на інформаційний простір, новітні засоби зв'язку допомагають терористам максимально довго зберігати конспіраиію.

Боротьба з тероризмом у переважній більшості держав має недолік - боротьба відбувається із уже виявленою терористичною активністю і ї наслідками. У такому випадку терористичні організації і терористи-одинаки можуть перебувати на стадіi підготовки до теракту або вже на стадіі його скоєння. 3 огляду на викладене вище виникає необхідність у створенні і забезпеченні таких умов, за яких ризик тероризму має мінімізуватись.

Явище антитерористичної безпеки в останні десятиріччя активно впроваджується у державні системи боротьби з тероризмом. На нормативно-правовому рівні держави окремо або в рамках співтовариств затверджують норми, що максимально ускладнюють виникнення і розвиток тероризму. Кожна держава має своє бачення антитерористичної безпеки і його відповідне впровадження у законодавство. Тому виникає потреба в аналізі систем забезпечення антитерористичної безпеки та їх нормативно-правовому порівнянні.

У статті здійснений порівняльний аналіз антитерористичної безпеки України і Російської Федерачії. Виявлені переваги і недоліки у трактуванні поняття «антитерористична безпека», його предметної області. Дослідженням встановлено, що в українському законодавстві поняття є більш глибоким і включає в себе розширений перелік об'єктів захисту.

Ключові слова: тероризм, антитерористична безпека, АТБ, Україна, Російська Федерація, боротьба з тероризмом, інформаційний простір.

Постановка проблеми. Сучасне суспільство постійно знаходиться на вістрі ризиків техногенного, технологічного, екологічного характеру тощо. Не менш руйнівною є загроза терористичного характеру. Наслідком такої загрози слугує кількість загиблих серед військовослужбовців на сході України, яка з 2014 року налічує понад 4 тис. осіб, а кількість загиблих серед цивільного населення понад 3 тис. осіб [1]. Допоки збройний конфлікт на сході нашої держави не закінчиться, ця кількість буде тільки зростати.

3 огляду на великі людські, матеріальні втрати, велику роль відіграють: можливість вчасно фіксувати ризики, іх аналізувати і формувати кваліфіковані інструкції з їх ліквідації; підготовка населення до виявлення ознак підготовки (вчинення) терористичного акту та формування відповідної компетентності у рамках забезпечення безпеки.
Концепцією боротьби 3 тероризмом в Україні визначається, що «на цей час найбільшу терористичну загрозу для України становить агресивна політика Російської Федерації» [2]. У зв'язку із цим виникає необхідність дослідження і порівняльноправового аналізу законодавства України та Російської Федерації у сфері забезпечення антитерористичної безпеки (далі - АТБ).

Аналіз останніх досліджень і публікацій. Загроза тероризму має глобальний масштаб, а тому був об'єктом вивчення багатьох закордонних науковців: Й. Александера, В. Дженкінс, К. Добсона, М. Креншо, Р. Пейна, Дж. Поуст, С. Селлігера, П. Уілкінсона, С. Хоффмана та інших.

Водночас залишається суттєвим внесок вітчизняних науковців у формування поняття і природи тероризму: В. Антипенка, В. Богданова, Д. Вєдєнєєва, В. Глуш- 
кова, В. Ємельянова, В. Крутова, В. Ліпкана, В. Остроухова, А. Петріва, І. Рижова, С. Скулиша та інших.

Утім, значна кількість публікацій закордонних і вітчизняних науковців присвячена організаційно-правовим засадам антитерористичної (і контртерористичної) діяльності, кримінологічним аспектам тероризму тощо. Натомість поза увагою науковців залишається порівняльно-правовий аналіз АТБ.

Мета статті. Здійснити порівняльно-правовий аналіз забезпечення АТБ в Україні та Російській Федерації. Визначити основні відмінності підходів забезпечення АТБ.

Виклад основного матеріалу. Постановою Уряду РФ «Про антитерористичну захищеність об'єктів (територій)» від 25 грудня 2013 року № 1244 закріплені правила розробки вимог до антитерористичної захищеності об'єктів (територій), а також паспорту безпеки об’єктів (територій) [3].

Вказаний вище документ врегульовуе організаційно-правові засади розробки відповідних документів щодо перешкоджання незаконному проникненню на об'єкт або територію, що підлягають захисту, попередження спроб вчинення терористичного акту та мінімізації можливих наслідків скоєння теракту тощо.

Окремої уваги заслуговує те, що вказаною вище Постановою Уряду РФ ступінь загрози вчинення теракту визначається на основі даних щодо вже скоєних або попереджених терактів. 3 огляду на еволюціонізм тероризму, його технічний і технологічний розвиток нами вбачається те, що цього не достатньо для своєчасного реагування на потенційні загрози. Крім того, велику роль відіграють політичні, економічні, соціальні процеси в державі і світі, що можуть сприяти формуванню і розвитку теророгенезу як сукупності соціальних, юридичних, кримінологічних процесів, що відбуваються в суспільстві і визначають походження і еволюційне формування тероризму [4].

На основі вимог Постанови Уряду РФ федеральні органи виконавчої влади (за погодженням із ФСБ і МВС РФ) розробляють методичні рекомендації і проекти актів щодо розробки паспортів безпеки. У більшості випадків методичні рекомендації мають типовий характер і зачіпають базові елементи забезпечення антитерористичної безпеки об'єкта: заходи охорони об'єктів захисту, дії співробітників охорони в екстремальних умовах тощо.

Зокрема були прийняті такі документи:

1) Постанова Уряду РФ «Про затвердження вимог щодо забезпечення транспорт- ної безпеки, в тому числі вимог до антитерористичної захищеності об'єктів (територій), які враховують рівні безпеки для різних категорій об'єктів транспортної інфраструктури і транспортних засобів повітряного транспорту» від 28 липня 2018 року № 886;

2) Федеральний закон РФ «Про внесення змін до статей 5 та 5.1 Федерального закону «Про протидію тероризму» від 18 квітня 2018 року № 82-Ф3 (цей закон спрямований на вдосконалення координації діяльності територіальних органів і федеральних органів виконавчої влади, органів виконавчої влади суб'єктів Федерації і органів місцевого самоврядування щодо профілактики тероризму, мінімізації та ліквідації наслідків його проявів на територіях муніципальних утворень);

3) Федеральний закон РФ «Про внесення змін до Кримінального кодексу Російської Федерації 3 метою вдосконалення заходів протидії тероризму» від 29 грудня 2017 року № 445-Ф3;

4) Постанова Уряду РФ «Про зміни в порядку зберігання і надання інформації 3 метою протидії тероризму» від 16 грудня 2017 року № 1576;

5) Постанова Уряду РФ «Про порядок підтвердження відповідності персональних даних абонентів, заявлених в договорах про надання послуг зв'язку, фактичним даним користувачів послугами зв'язку» від 25 жовтня 2017 року № 1295;

6) Постанова Уряду РФ «Про затвердження вимог до антитерористичної захищеності торгових об'єктів» від 19 жовтня 2017 року №1273;

7) Постанова Уряду РФ «Про затвердження вимог до антитерористичної захищеності об'єктів освіти і науки» від 7 жовтня 2017 року №1235;

8) Постанова Уряду РФ «Про порядок створення зон безпеки об'єктів використання атомної енергії» від 26 червня 2017 року № 749 .

Втім, вважаємо за необхідне звернути увагу на термінологію. Відповідно до Федерального Закону «Про внесення змін в окремі законодавчі акти Російської Федерації з питань антитерористичної захищеності об'єктів» від 23 липня 2013 року № 208-ФЗ антитерористична захищеність об'єктів є «стан захищеності будівлі, споруди, іншого об'єкта, місця масового перебування людей, що перешкоджає здійсненню терористичного акту. При цьому під місцем масового перебування людей розуміється територія загального користування поселення або міського округу, або спеціально відведена територія за їх межами, або місце загального користування в будинку, будові, 
спорудженні, на іншому об'єкті, на яких за певних умов може одночасно перебувати більше п'ятдесяти чоловік» [5].

Поняття антитерористичної безпеки звужується до стану захищеності об'єктів (споруд, установ, підприємств) і місць масового перебування людей від вчинення терористичного акту. Таке трактування АТБ є дещо обмеженим, оскільки воно еволюціонувало у більш широке поняття. Зокрема, об'єктом забезпечення АТБ можуть бути не тільки установи, підприємства тощо, пошкодження або знищення яких може нанести невиправну шкоду державі. Якщо підходити до цього зворотно від ієрархії цілей терористичної діяльності, то забезпечення АТБ може здійснюватися і відносно таких об'єктів: інформаційне середовище (кіберпростір, медіапростір, блогосфера), соціальні системи (фізичні та юридичні особи, громадська безпека, суспільна свідомість, соціальна безпека) [6, с. 92-94]. Звісно, фізично виміряти шкоду суспільній свідомості доволі важко, проте вона може піддаватись інформаційному впливу, що, зрештою, призведе до деструктивних наслідків у суспільстві і державі.

Водночас Концепцією боротьби з тероризмом в Україні від 05 березня 2019 року визначається, що об'єктом можливих терористичних посягань (тобто об'єктом забезпечення антитерористичної безпеки), крім об'єктів матеріального світу (споруди, майнові комплекси, підприємства, установи тощо), можуть бути інші об'єкти, що можуть не мати фізичної форми, але відіграють не менш важливу роль у безпеці держави і її головного елемента - суспільства.

Антитерористична безпека держави спрямована на забезпечення захисту об'єктів можливих терористичних посягань і терористичних загроз. До таких об'єктів відносяться: «Фізичні особи та громадські об'єднання, державні органи, органи місцевого самоврядування, підприємства, установи та організації незалежно від форми власності, ділянки місцевості або території, інформаційний простір та його компоненти, споруди або майнові комплекси, об'єкти транспортної інфраструктури та інші об'єкти, стосовно яких можуть вчинятися терористичні акти» [2].

Вважаємо за необхідне звернути увагу на такі ключові елементи визначення переліку об'єктів можливих терористичних посягань.

Інформачійний простір та його компоненти. За М. Слюсаревським, інформаційний простір є станом (результатом) перманентної взаємодії процесів виробництва і споживання інформації. Обгрунтовуючи реляційну теорію інформаційного простору, науковець характеризує інформаційний простір не стільки за площиною розповсюдження інформації або за іiї об'ємом, а за інтенсивністю і обсягами їі споживання [7, с. 341]. Такий підхід є абсолютно раціональним, оскільки збільшення об'єму інформації не гарантує прямо пропорціональне збільшення її споживання.

Інформаційний простір у XXI столітті має особливо яскраво виражений соціальний характер, де в центрі стоїть суб'єкт, який накопичує, продукує, передає i споживає інформацію. До таких суб'єктів можна віднести особистість, соціальну групу, юридичну особу, органи державної влади. Глобалізаційний і інтегративний у сучасне суспільство характер інформаційного простору впливае на основні сфери суспільства: економічну і суспільно-політичну. Такі процеси здійснюються за допомогою таких компонентів системи інформації і зв'язку: технологічні можливості розповсюдження інформації (інформаційна інфраструктура); вертикальні і горизонтальні системи поширення інформації; засоби інформаційної взаємодії; інформаційні ресурси.

Таким чином, інформаційний простір як об'єкт можливого терористичного посягання $€$ вкрай цінним об'єктом забезпечення АТБ.

Інші об'єкти, стосовно яких можуть вчинятися терористичні акти. Еволюціонізм суспільства $€$ процесом постійним, який супроводжують розвиток технологічних, суспільних, економічних, політичних сфер діяльності людини. Результати такого розвитку швидко інтегруються у суспільне життя і стають його частиною, а тому створюють для терористичної діяльності нові об’єкти для здійснення атак.

Для XX століття більш характерними видами терористичних атак були напади із вогнепальною зброєю, здійснення спланованих вибухів або використання іншої зброї, що так чи інакше слугувала для нанесення фізичної шкоди тощо. Сьогодні ж ми спостерігаємо широке використання новітніх методів терористичної діяльності, що стають більш дистанційними, але не менш деструктивними для держави. Серед інших найчастіше використовуються кібератаки, коли зловмисники прямо або через спеціальні програми (віруси) намагаються отримати повний контроль над комп'ютерами чи вивести їх з ладу. Новітні досягнення у сфері інформаційних технологій стають для терористів інструментом для реалізації своїх задумів. Наприклад, використання інтегрованих в електронні месенджери захищених каналів зв'язку дозволяє терористам вести підготовку до здійснення теракту із мінімальною вірогідністю їх розкриття.

Такі можливості розвитку суспільства, технологій закладені в Концепцію боротьби 3 тероризмом в Україні. Держава розуміє, що в будь-який момент можуть з'явитися нові 
об’єкти, стосовно яких можуть вчинятись терористичні акти, а тому потребуватимуть захисту з боку держави.

\section{Висновки}

Аналіз нормативного забезпечення показав, що погляди на АТБ в Україні і Російській Федерації мають суттєві відмінності. До таких слід віднести:

1. Аналіз загроз. Спираючись лише на досвід нейтралізації наслідків вчинених або попереджених терористичних актів, неможливо бути готовими до загроз, що можуть суттєво відрізнятись від вже відомих. Тому потребується аналіз явищ, що можуть прямо впливати на стан АТБ в державі.

2. Об'єкти захисту від можливих терористичних посягань. На сьогоднішні інформаційний простір стає не тільки джерелом отримання актуальних даних, а й засобом формування суспільної думки. Захист інформаційного простору має стратегічне значення для безпеки держави, а тому є важливим об'єктом АТБ.

3. Стратегічні погляди на потенційні загрози. Держава не може бути повністю готовою до нових, раніше не відомих викликів. Утім, цілком можливо корегувати дії держави відповідно до потенційно можливих ризиків.

У даній науковій статті здійснено порівняльний аналіз АТБ лише кількох держав, а тому існує необхідність у подальших наукових розвідках у сфері АТБ і нормативно-правовому аналізі систем АТБ інших держав для вдосконалення вітчизняної.

\section{Список використаних джерел:}

1. Книга пам'яті полеглих за Україну: сайт. URL : https://memorybook.org.uа (дата звернення: 14.12.2019)/

2. Указ Президента України «Про Концепцію боротьби з тероризмом в Україні» від 05 березня 2019 року № 53/2019: сайт. URL : https://zakon. rada.gov.ua/laws/show/53/2019 (дата звернення: 14.12.2019)

3. Об антитеррористической защищённости объектов (территорий): сайт. URL : http:// government.ru/docs/9419/ (дата звернення: 14.12.2019)

4. Рижов I.М. Умови формування теророгенності соціальних систем та законодавство України. Форум права. 2013. № 2. С. 480-486

5. Федеральный закон от 23 июля 2013 г. № 208-ФЗ «О внесении изменений в отдельные законодательные акты Российской Федерации по вопросам антитеррористической защищенности объектов» (с изменениями и дополнениями) : сайт. URL : http://base.garant.ru/70419060/ (дата звернення: 16.12.2019)

6. Рижов І.М., Кудінов С.С., Івахненко О.А. Основи антитерористичної безпеки соціальних систем : монографія. Київ : Кафедра, 2017. 212 c.

7. Слюсаревський M.M. Інформаційний простір: критика існуючих визначень і спроба побудови теорії. Харківський держ. ун-т. Вісник. Харків, 1999. № 439, ч. 4, 5: Сер. Психологія, політологія: Особистість і трансформаційні процеси у суспільстві. С. $337-342$.

Kostyantyn Havrilyuk. Comparative analysis of anti-terrorism security in Ukraine and the Russian Federation

The article considers the regulatory and legal support of anti-terrorist security in Ukraine and the Russian Federation. Differences have been established that fundamentally differentiate views on anti-terrorist security.

Today, the threat of terrorism is international. The vast majority of terrorist organizations are transnational in nature, and therefore the preparation for a terrorist attack, its location and consequences extend to several (or more) countries. In addition, the methods of committing terrorist attacks are changing and evolving: the latest types of weapons are being used, the information space is being influenced, and the latest types of communication are helping terrorists to keep the conspiracy as long as possible.

The fight against terrorism in the vast majority of countries has a drawback - the fight is against the already identified terrorist activity and its consequences. In this case, terrorist organizations and lone terrorists may be in the process of preparing for a terrorist attack or already at the stage of its commission. In view of the above, there is a need to create and ensure that the risk of terrorism is minimized.

The phenomenon of anti-terrorist security has been actively introduced into state counter-terrorism systems in recent decades. At the regulatory level, states, individually or within communities, approve norms that complicate the emergence and development of terrorism as much as possible. Each state has its own vision of anti-terrorist security and its proper implementation in law. Therefore, there is a need to analyze antiterrorist security systems and their regulatory comparison.

The article provides a comparative analysis of the anti-terrorist security of Ukraine and the Russian Federation. The advantages and disadvantages in the interpretation of the concept of "anti-terrorist security", its subject area. The study found that in Ukrainian law the concept is deeper and includes an expanded list of objects of protection.

Key words: terrorism, anti-terrorist security, ATS, Ukraine, Russian Federation, counter-terrorism, information space. 